\title{
Mitigation of flood hazards in Japan
}

\author{
M. Takezawa ${ }^{1}$, H. Gotoh ${ }^{1} \&$ Y. Takeuchi ${ }^{2}$ \\ ${ }^{I}$ Nihon University, Tokyo, Japan \\ ${ }^{2}$ Japan Infrastructure Partners
}

\begin{abstract}
In recent years, there have been instances of unusually heavy rain in Japan, including rainfall in excess of $200 \mathrm{~mm} /$ day. The aim of flood-control planning in Japan since 1945 has been to confine river water to within riverbanks and to ensure that levees protect river basins from flooding. In many rivers, dams were constructed in upstream areas and long levees were built along the riverbanks. The main aim of flood-control planning is to prevent the flooding of river basins by the over-flow of river water across riverbanks; however, as rainfall prediction has recently become difficult because of the effects of global warming, the main emphasis of flood-control planning has shifted from prevention to providing areas of refuge. Flood hazards must be dealt with by 'hard measures' such as levees and reservoirs, and 'soft measures' such as the provision of hydrological information, regulation of land use, and evacuation advice. In 2001, the Japanese Government made it mandatory for all regional bodies to compile and distribute flood-hazard maps to inform inhabitants of the danger of flooding and the locations of sites of refuge for all inhabitants.

It is difficult to provide residents with complete protection from flooding hazards. Many people in Japan live alongside rivers, and Japanese culture has long encompassed wet-rice cultivation. Communities have always lived under the threat of flooding, but the profitability of river water makes it preferable to live close to a river even if flooding occurs at times of heavy rain.

In this paper, we describe measures taken to mitigate flood hazards and present a number of case studies.

Keywords: flood hazard, mitigation, flood control, rainfall, river basin.
\end{abstract}




\section{Introduction}

Flood events have been occurring with alarming frequency all over the world; this may reflect abnormal weather associated with global warming. When all of the different types of natural disasters are considered, more than half of the associated fatalities are due to flooding, and almost half of the overall disasterrelated losses result from flooding [1].

Rivers in Japan are generally short and steep, meaning that rainfall flows rapidly from the river system; this increases the risk of flooding. About $70 \%$ of Japanese citizens live within river basins and in coastal areas. Following World War II, the construction of dams and levees was encouraged to protect areas damaged during the war and to generate hydroelectric power; however, this resulted in destruction of the environment, and in recent years some of the levees have been breached by floodwaters.

Since the 1900s, small rivers in Japan have been reclaimed to provide extra land and serpentine rivers have resulted from river-improvement projects. Trees along rivers have been cut down and natural banks replaced by concrete ones; consequently, water quality has deteriorated and various ecosystems within river basins have been destroyed with the construction of dams intended to provide hydroelectric power, the development of water resources, and flood control in upstream areas. Fish species have lost their breeding sites and wild birds have lost important habitat areas. With the construction of dams and levees, the landscape changed over a short time period and rivers became confined to artificial channels.

Ironically, the scale of flooding has increased as flood-control measures have been implemented. Artificial channels mean that rainwater is rapidly discharged into the sea, but the flux of river water increases temporarily following rainfall. Moreover, the area of river basins has increased with ongoing river improvements and the extent of forests and fields that store water has decreased; consequently, discharge has increased. To address this problem, the heights of levees have been increased, and the development of river basins was advanced once again. This led to a further increase in discharge as the cycle repeated itself. This cycle highlights the limitations of river engineering; it is therefore necessary to change the approach taken to river improvements.

The approach toward flood control in Japan recently changed from one of containment to one of allowance. The fact that there are many rivers and mountains in Japan means that large numbers of people live upon alluvial plains that are made up of river-deposited earth and sand. While river basins within alluvial plains must be protected by levees, it is also important to protect the environment and ensure human safety by undertaking river-improvement projects. It is therefore necessary to change our approach to disaster prevention from a complete dependence upon levees and dams. It goes without saying that we treasure the forests in upstream areas of river systems and that we must evacuate rapidly to shelters during times of flooding. We work tirelessly to find ways of dealing with floods but choose to return to the river after each flood event to commune with nature. 


\section{History of flood hazards and flood-control measures in Japan}

Stories of flood hazards have been handed down from generation to generation by many different peoples across the world; the story of Noah's flood is the most famous of such accounts. There are many different flood-related myths in Japan that involve a dragon or snake.

The history of flood control in Japan can be subdivided into four stages [2]. The first stage, prior to the Meiji Restoration in 1865, was one of symbiosis with flooding that sought to minimize flood damage associated with the flow of rivers across their banks by excluding settlements from flood-prone areas. The Japanese of the Jomon Period (10,000-4,000 BC) did not require the use of fertile flood-prone fields for agriculture because they were hunters; however, they began to make use of alluvial plains as farmers during the Yayoi Period (4,000-3,000 BC). The change to a farming lifestyle led to an increase in production capacity and a concentration of the population upon fertile floodplains. The remains of a Yayoi Period village reveal an irrigation canal around the village and the trace of a large ditch and embankment to protect the site from flooding. Paddy fields were developed on flat land alongside small rivers, and the population in Japan grew from 0.7 millions to 2.5 millions between 50 and $200 \mathrm{AD}$. Large-scale river-improvement projects were undertaken during the Kofun Period (200-600 AD) when iron tools were first developed for farming. For example, the excavation of a canal was planned by the Emperor Nintoku and an embankment was constructed in Manda (Figure 1). Legal codes established over the period 600-900 AD led to substantial river improvements: the construction of dikes, ponds, and ditches was considered the duty of provincial governors. In the Middle Ages, from the 12th to the 16th centuries, many valley ponds were constructed in hilly areas and dike-protected areas of the polder (Wajyutei) [3] were constructed to protect a village from the Kiso, Nagara, and Ibi rivers (Figure 1). The river improvements undertaken during the Warning State Period (900-1600 AD) included the construction of flood control of the Kamanashi River by General Shingen Tekeda (1521-1573 AD), who was in charge of the Kofu district (Figure 1). General Takeda protected the Kofu Basin from a succession of flood hazards by constructing one-sided levees along the Kamanashi River. These measures led to a $76 \%$ increase in the production of paddy rice during the approximately 150-year period from the Keicho Era (1596-1615 AD) to the Houreki Era (1751-1764 AD).

General Ieyasu Tokugawa (1793-1853 AD) initiated improvements to the Tone and Arakawa rivers (Figure 1) when he established the Tokugawa Shogunate in Edo (present-day Tokyo). He increased the area of farm land by restricting the area of flooding and used flood-control works to transport floodwater to the Tone and Arakawa rivers. Tadatsugu Ina (1550-1610), chief retainer of General Ieyasu Tokugawa, supervised the exploitation of the Tone River. His technique, termed the Kanto or Ina method, involved the use of natural landforms, the strengthening of natural levees, the construction of 
reservoirs, dispersal of the force of the flood, and protection of important sites by the construction of low crown levees. His approach to flood control was to tolerate minor damage due to partial flooding because sediment deposited by the floodwaters provided fertilizer for agricultural land. In this way, rivers and their immediate environment were able to live close together. Consequently, the population of Japan grew from $10,000,000$ to $30,000,000$ during the period 1550-1700 (during the first stage of flood control in Japan), and the area under cultivation increased from 10,000 to $29,500 \mathrm{~km}^{2}$ because paddy fields increased in size with the changes made to large river channels. The rapidly increasing population meant that in 1865 the Japanese Government adopted the policy of increasing the food supply by developing paddy fields alongside rivers; consequently, many farming people came to live in dangerous flood-prone areas.

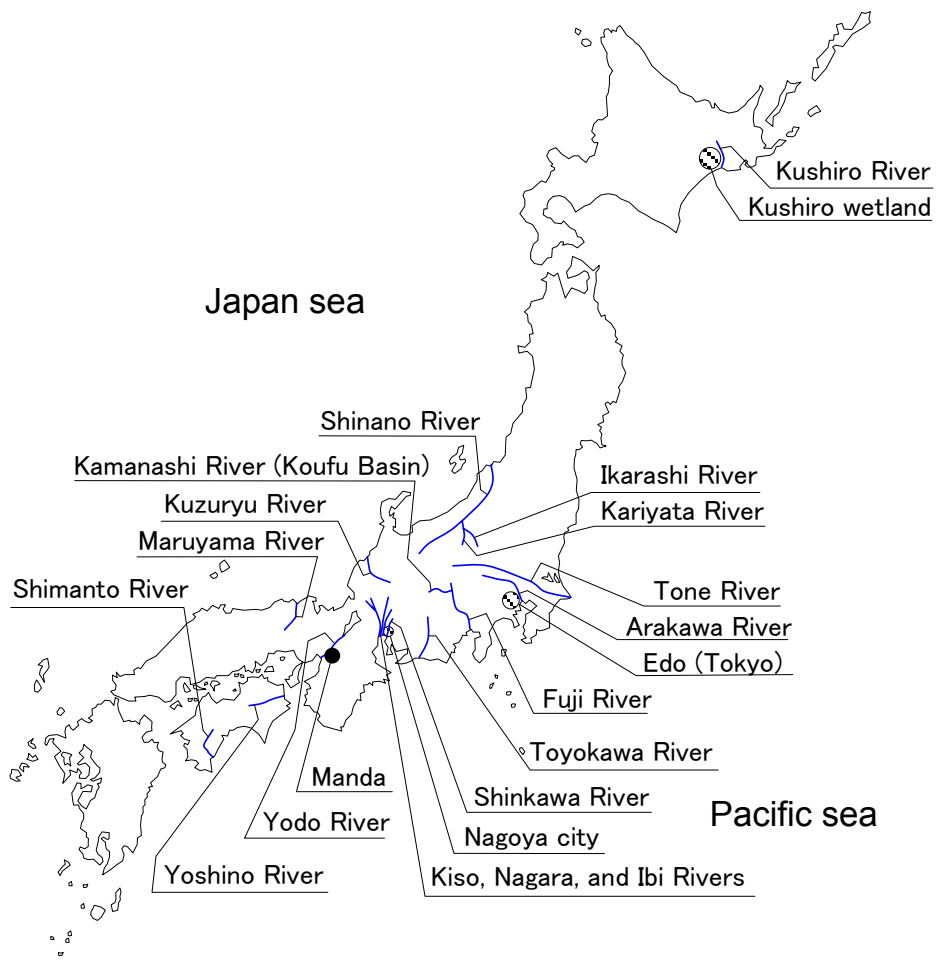

Figure 1: $\quad$ Rivers and places described in this paper.

To protect these vulnerable farmers, continuous and high river levees were constructed along large rivers located on alluvial plains. This marked the start of the second stage of flood control in Japan, and from 1865 river projects were undertaken to keep floodwaters within the river channel. The policy of flood control following the Meiji Restoration (1867) was based on western ideas that became enacted in government legislation. Many foreign engineers were invited 
to Japan by the Meiji Government to pass on their techniques to local engineers. These foreign specialists mainly practiced techniques of river maintenance and water transportation that were developed in Europe. In 1873, the Meiji Government passed regulations governing the repair of rivers, harbors, and roads. Under the direct control of the Meiji Government, river-maintenance projects concerned with water-borne transportation and safety were carried out on 14 rivers, including the Yodo, Tone, and Kiso (Figure 1). Projects on other rivers were carried out by the state representative of the Meiji Government. However, a succession of flood events and the change from water-borne to landbased transportation (mainly railroads) led to a change in the river policy of the Meiji Government. Following the passing of the River Law of Japan in 1896, large-scale flood-control projects were promoted by the Japanese Government. For example, improvements were made to the Kuzuryu River, the waterway of the Shinano River was partitioned, and drainage works were undertaken for the Arakawa River (Figure 1).

Private title over rivers was ruled out by the River Law of 1896, such that all official works on rivers were integrated into the executive right of the Minister for Home Affairs; that is, the Japanese Government gained control of all of the rivers in Japan. Policies on irrigation and flood control were passed during the Taisyou Era (1912-1926). The main objective of these policies was to attain improvements in agricultural productivity; that is, flood control and agriculture were two sides of the same coin. Government policy in regard to agriculture was enforced in the Irrigation Combination Acts and the Cultivated Arrangement Law. Since World War I, urbanization and industrialization in Japan has led to increasing demand for water for industrial use. This led to the serious problem of whether agriculture was to be superceded by industry in terms of the priority assigned to water use. During the first stage of flood control outlined above, flood-related standing water drained quickly from the land; in contrast, during the second stage floods were frequent and floodwater receded extremely slowly.

The third stage of flood control encompassed the period of rapid urbanization and increasing population following World War II. The River Law of Japan was revised in 1964 following increased demand for water. During the third stage, multipurpose dams were constructed with the aim of flood control, irrigation, and the generation of hydroelectric power. The river manager, who was the Minister for Rivers in the case of first-class rivers, the Governor of the Prefecture in the case of second-class rivers, and the Mayor of the local community for other classes of rivers, was defined in the River Law, which was revised in 1964. The basic plan for first-class rivers was determined by the River Council, which operated outside of the Land, Infrastructure, and Transport Ministry. The maintenance of rivers was carried out at short notice as required in terms of flood control and water use, but the harmful environmental effects of public works worsened with the passing of the revised River Law. Although flood control is important in terms of saving lives, river works quickly destroyed ecosystems that had developed over long periods of time.

In 1997, the River Law of Japan was revised once more, and artificial measures of flood control, irrigation, and environmental management, etc., were 
introduced [4]. Namely, the fourth stage of flood control involved a change in approach to flood control from disaster prevention to flood mitigation. Recently, societies interest in the ecosystem has increased because of a growing awareness of environmental problems. Many ideas for valueless river-improvement projects and dam construction are proposed by people who live within river basins, but the way in which people think about rivers is being changed by the civil service. The main points of the 1997 River Law include the following: (1) to consider the ecosystems of wildlife, (2) to preserve water-cycle systems, and (3) to review the relation between rivers and adjacent areas. This represents a marked change in the policy position of the River Law in terms of the environment. The supposedly extraordinary events of water shortages and flooding were the prime focus of earlier versions of the River Law, but rivers are now recognized as a part of our daily life in relation to the policy toward rivers during peace times. In the future, it is important to take part in the servicing and management of rivers along with political officers and that the administration takes a leadership role. People living within river basins must understand the importance of river basins from the source of the river to the estuary; people and nature must live close together.

\section{Flood-hazard mitigation plan}

In Japan, rivers tend to be flooded during heavy rain because of natural and social factors. In the past, Japanese planners considered that flood-control works should conform to the natural characteristics of rivers. For example, floodcontrol works involved rock cribs (Seigyu), gabions, stone-pitched groynes (Shogi head), etc. (Figure 2 and 3), developed by General Shingen Takeda [5].

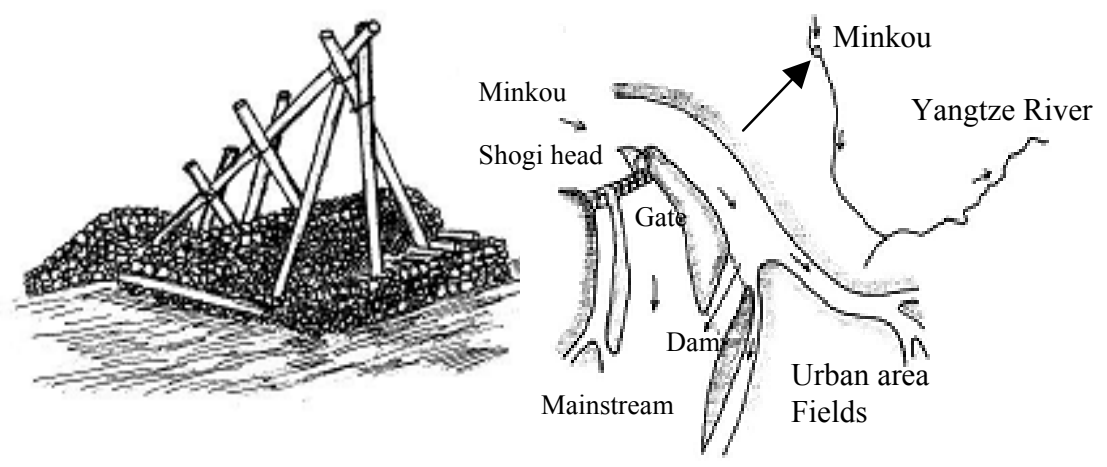

Figure 2: $\quad$ Seigyu and gabion.

Figure 3: Du Jiang Yan.

It has been said that his works were adopted from the techniques employed for Du Jiang Yan (Figure 3) in China [6]. These types of works conform to the nature of the river and tie in with the surrounding environment because natural materials (wood, stone, bamboo, etc.) are used in their construction. The Du Jiang Yan was maintained by the director Hyou Lee over the period 
306-251 BC. Hyou Lee developed the method of controlling flooding by deepening the riverbed and constructing a low dam. The Du Jiang Yan controlled the flooding of the Minkou (Minjiang) at a branch of the Yangtze River (Chang Jiang), which was an important source of livelihood, by controlling the depth of the riverbed and the elevation of the dam based on empirical knowledge. Instructions were set in a sutra to create a saying related to flood control: to dredge river beds, to construct levees, to lay stones as fish bill, to set tree fence, to flood by channels, to divide flow for 4 to 6 by gabions, to write the basic water level, to set a basic marker at river beds, and to have respect for the old system. Moreover, the flood-control manual describes ways to ensure a smooth river flow by removing sandbar corners at revetment works, canceling the energy of divisional flows, and being flexible in the face of changing times and places by understanding the force of flow and other natural conditions.

Flood-hazard mitigation involves any task that can be undertaken to minimize future economic losses and eliminate threats to public safety resulting from flood hazards. The basis of a mitigation plan is an inventory and map of all of the known or predicted areas that might suffer economic damage resulting from heavy rain, extreme runoff, or flooding. Finally, a flood-hazard mitigation plan includes a prioritization of problem areas (according to pre-flood, syn-flood, and post-flood categories) and an Action Plan to eliminate these economic losses by undertaking a sustained effort over a long period of time [7].

The following actions can help to reduce losses and minimize the risk of hazards. 1) Purchase undeveloped flood-plain land to use as open spaces such as parks and forest reserves. 2) Relocate, elevate, or flood-proof homes, buildings, and structures. 3) Develop reservoirs, wetlands, and regional storm-water management facilities. 4) Rebuild roads above flood levels using expanded openditch drainage for water storage. 5) Build or upgrade water supplies, sanitary sewers, and storm sewers with increased capacity and water-tight connections. 6) Build levees and channel diversions around valuable, easily damaged areas. 7) For property that is easily protected, anticipate floods and deploy sandbags as early as possible. 8) Purchase flood insurance. Recently, levees in Japan have been breached by large flood events with enormous amounts of resulting damage.

Flood hazards in urban areas have been increasing every year. The development of failsafe protection against flooding is impractical; consequently, it is necessary to reconstruct the urban area to ensure that it is resistant to flooding hazards. Large first-class rivers managed by the Japanese Government are measured on the basis of flooding every 100-200 years, but the construction of levees and dams is unable to keep pace with that required to prevent flooding. Until now, flood-control measures have focused on containing river flow with the construction of levees alongside rivers and the construction of dams across upper streams; however, recent record heavy rains and a reduction in the funds available for public works have led to new flood-control systems that seek to minimize flood hazards. For example, one residential street is protected by two lines of levees [8] constructed alongside the adjacent river. The two lines of levees are created by elevating the road and the railroad that lie between the 
cluster of houses and the field. The area that cannot be protected by the levees is not adversely influenced by constructing the circular structure that encloses the residential area and the field.

The National Flood Insurance Program's Community Rating System in the USA [9] encourages a review of six general mitigation strategies: 1) prevention activities that keep problems from worsening, 2) property protection is usually undertaken by property owners on a building-by-building or parcel basis, 3) emergency services measures are taken during a flood to minimize its impact, 4) structural projects are employed keep flood waters away from a protected area, 5 ) natural resource protection preserves or restores natural areas or the natural functions of floodplains and watersheds, 6) public information programs advice property owners, potential property owners, and visitors of local flood hazards as well as ways in which to protect people and property.

In a White paper [10] by the Land, Infrastructure, and Transport Ministry, the Japanese Government addresses flood hazards by clearly emphasizing conservation, regeneration, the creation of a sound environment, and taking environmental responsibility; that is: 1) the conservation and formation of a healthy river environment such that the river consists of various natural environments and enjoys natural rejuvenation, 2) the recovery of water volumes in rivers such as the termination of falling sections of river, 3) the continuity of organisms and sand such as a course for fish and sand supply, 4) reconstruction of the area between towns and rivers to encourage interaction between people and rivers, and 5) environmental education about rivers such as those activities undertaken by the River Activities Council.

\section{Case studies}

Levees of the Kariyata and Ikarashi Rivers (Figure 1) in Niigata Prefecture, Japan, which were branches of the Shinano River, gave way in 2004 during heavy rain that was part of a 300-year flood event [11]. About 10,000 houses were flooded and 12 people were drowned during the flooding. A flood-control dam located upstream and levees withstood a 100-year flood in the Kariyata River. Two flood-control dams were also constructed upon the Ikarashi River; however, the rainfall that fell was higher than that expected. Following the flood, the policy of flood control in Niigata Prefecture was revised; that is, the upstream levees were constructed lower than previously and a retarding basin was planned for about 100 ha of paddy fields to ensure that water overflow across the levee was guided to the retarding basin, which is devoid of people. About 400 houses in areas of high flood risk were moved to safer areas in Ikarashi; residents in the basin of the Ikarashi River preferred to shift rather than safeguard their existing homes.

The levees of the Asuwa River (Figure 1) in Fukui Prefecture, Japan, were destroyed by heavy rainfall in 2004; many houses were flooded. Approximately $60 \%$ of those injured during the flood were elderly; consequently, the government devised guidelines for supporting refugees in the case of a disaster [11]. Moreover, information on flooding was revised to make it easy to 
understand for all readers. For example, the difference between 'dangerous water levels' and 'special precaution water levels' was clearly explained.

The Shimanto River (Figure 1) in Kochi Prefecture, Japan, is known as a clear river. The upper stream contains a hydropower dam that is $80 \mathrm{~m}$ high; the river has a total length of $196 \mathrm{~km}$ [11]. The water taken from the river for power generation is generally later discharged downstream of the dam, but some water is discharged into the Iyoki River, which then makes its way to the sea. Therefore, water only flows downstream of the dam when there is no flood risk. The quantity of discharged water is 1 tonnage per second for 190 days of the year, with no water discharged for 90 days of the year for the $20 \mathrm{~km}$ section from the dam to a point where a large branch occurs in the river. In this section of the river, water activities and fishing are prohibited. A plant that rises from the ground was used rather than a waterside one; however, the quantity of water is still abundant in the downstream area of the Shimanto River because there are many branches of the river. The operation of the dam does result in deterioration of the quality of water and a reduction in the fish catch because $30 \%$ of the total water volume is captured by the dam. Residents and fishermen in the middle and lower reaches of the river are appealing for the dam to be opened and for the water to be returned to the river. Given that global warming is an important issue, the generation of hydroelectric power is a valuable energy source; however, the natural recovery of the river, as represented by clear river water, has an important value that exceeds the value of hydroelectric power that is generated using water taken from the river.

The upper reaches of the Yoshino River (Figure 1), Shikoku Island, contain 370 ha of flood-defense forest that is the largest bamboo thicket in Japan [11]. The force of the water that overflows from the river is mitigated by the forest, and sand is trapped by the vegetation; consequently, flooding has been reduced over the past 100 years. However, the Japanese Government has recently proposed the construction of a movable dam for the purpose of the river improvement. Local people are protesting that the Japanese Government is intent on destroying nature and wasting money.

A wide reservoir was constructed in Toyohashi City, in the downstream part of the Toyokawa Stream (Figure 1), Aichi Prefecture, during the Edo Period (1600-1860) [11]. The reservoir is surrounded by an open levee (the Kasumitei levee) that contains gaps through which the water preferably overflows. A thick copse grows adjacent to the levees, and the reservoir is used as a field in times of normal river flow. The Japanese Government plans to construct a dam in the upper stream to remove the need for the reservoir and copse, but local people oppose this scheme. The nature of flooding-related river improvements in this area has been employed since the Edo Period, although it involves the sacrifice of farmland.

Heavy rain associated with a typhoon on October 23, 2004 led to serious damage, the flooding of 11,874 households, and the inundation of 4,083 ha by the Maruyama River (Figure 1), which flows through the Toyooka Basin in Hyogo Prefecture [11]. Following the flood, the "Nature Revival Plan in the Maruyama Water System" was devised in November, 2005. The plan states that 
the recovery of nature should be compatible with river improvement measures; that is, improvement measures largely involve the upkeep and regeneration of meadows. Residents within the river basin are proceeding with a course of action that aims to reproduce a river environment in which various creatures and people live together with the cooperation of local inhabitants.

The Kushiro River (Figure 1), which flows across the wet Kushiro Plain in Hokkaido, is slated to be returned to its original meandering form after having previously been straightened as a flood-control measure [11]. The Kushiro originates from Kussharo Lake and passes down the Ramsar Convention registration damp ground and the Kushiro damp plain before flowing into the Pacific Ocean. The incidence of flooding fell once the river was straightened, but the damp plain began to dry out because earth and sand inflowing from the upper reaches of the river increased and $20 \%$ of the area of wetlands disappeared over the course of half a century. In response, the Japanese Government filled in a $1.6 \mathrm{~km}$ stretch of straightened river 25 years ago and brought back a $2.7 \mathrm{~km}$ stretch of meandering through.

A total of 70,000 houses were flooded and 10 people died in Aichi Prefecture during flooding in September 2000 [11]. The damage amounted to 980 billion yen. This disaster represents a typical city disaster. The municipality of Nagoya City in Aichi Prefecture has developed an evacuation procedure, but during the flood event the rainfall intensity was twice the assumed rate of $50 \mathrm{~mm} / \mathrm{hr}$. Accordingly, there was insufficient time to evacuate residents because of the rapid increase in water level within the river. A highway was flooded and the river overflowed into a subway station. A small river within the urban region overflowed because of the heavy rain. The Shinkawa (Figure 1), which collapsed during the heavy rainfall, is a small river that flows through Nagoya City. The city had been purchasing riverside land to improve the levees. A reservoir with a capacity of $100,000 \mathrm{~m}^{3}$ is located under a road of about $100 \mathrm{~m}$ in width; the reservoir passes underground through the center of Nagoya City in the east and west directions. This reservoir performs the role of preventing rainwater from flowing into the river; the water is pumped into the river once the water level has subsided. However, the reservoir was cut off at the time of this disaster and did not function. It is an important to undertake measures such as the maintenance of levees, drainage works, and reservoirs; however, there is a limit to such maintenance work due to budget constraints. Therefore, it is an important to evacuate residents with reference to a hazard map in the case of heavy rain that exceeds assumed rainfall intensities.

\section{Conclusions}

A disaster culture was firmly rooted in the minds of residents in previous times, but all sense of impending flood disasters has become forgotten with the construction of levees and advances in sewage maintenance. The fluidity of inhabitants in a city is high and the disaster culture has not survived. People have changed in terms of water use with changing land use. Residential development and the construction of factories have advanced with the security provided by 
construction projects; however, significant damage occurs when the amount of rainfall exceeds the limit of river-improvement measures. This situation has resulted from a lack of unity in administering land use and rivers. If there is information on flood damage, it is easy to avoid such damage. The administration must hurry in reporting to inhabitants during times of heavy rain. It is difficult to pass new laws and regulations for existing cities; therefore, it is necessary at the time of rebuilding a house, for example, to construct a structure that enables rainwater to infiltrate the ground.

The continuation of a Basin Committee established at the district maintenance station of the Ministry of Land Infrastructure and Transport has been placed in danger. The River Law was revised in 1997 to ensure that river plans reflect the opinion of local inhabitants. This is the first step of a Basin Committee method that includes local inhabitants in deliberations concerned with river planning. The Basin Committee gave a commitment in 2003 not to build new dams. In contrast, the Bureau of Rivers within the Ministry of Land, Infrastructure and Transport blocked the construction of just two of five dams proposed in 2005. It is now common for local residents to oppose the construction of new dams. As the true intention of the Ministry of Land, Infrastructure and Transport is to suppress the voice of local residents, the Basin Committee is necessary because there is opposition to new dams. The interest taken in a river increases among residents when maintaining a river according to the revised River Laws because residents participate in meetings of the Basin Committee; consequently, residents are aware of the dangers during floods and are involved in improving local disaster-prevention measures.

\section{References}

[1] Kron. W., Dealing with Flood Risk, Stockholm Waterfront, No.3, pp.16, 2006.

[2] JICA, Disaster Prevention and Development, http://www.jica.go.jp

[3] Wikipedia, Polder, http://ja/wikipedia.org/wiki

[4] Bureau of River, Ministry of Construction, On the revised River Laws, http://www/mlit.go.jp/river/gaiyou/houritu/9705.html

[5] Wada, K., Graph Shingentei, Yamanashi Nichinichi News, 2003

[6] http://homepage 2. nifty.com/yama56/chengdu4.htm

[7] Warner, M.D., SMC Flood Hazard Mitigation Plan, http://www.co.lake.il.us/smc/planning/flood/plan.asp

[8] Wetmore F. and Jamieson G., Flood Mitigation Planning: CRS Approach, National Hazard Informer http://www.colorado.edu/hazards/informer/ intrmr/infrmr/a.htm

[9] http://www.thy.mlit.go.jp/Bumon/ J7420/

[10] Ministry of Land, Infrastructure and Transport, Japan, The White Paper, 2006.

[11] Asahi Newspaper (in Japanese) 